\title{
Uncovering and Developing Industry Clusters
}

\author{
Adee Athiyaman \\ Western Illinois University \\ E-Mail: A-Athiyaman@wiu.edu
}

\begin{abstract}
This paper observes that the existing definitions of clusters can be grouped under two categories: intra-industry clusters, and inter-industry clusters. Economic geographers and strategy researchers suggest "intra industry" conceptualisations of clusters. Regional economists subscribe to the Porterian model of clusters that focuses on inter-industry linkages. While we agree that clusters should assess interindustry linkages, we argue that the process of identifying clusters should begin at the intra-industry level. A conceptual framework based on 'strategic groups' theory and value system analysis is developed as an explanation for industry clusters.
\end{abstract}

Keywords: Strategic Groups, Value System Analysis, Regional Economics

\section{INTRODUCTION}

Most industrialized nations have adopted some type of regional development program designed to encourage the industrial and economic development of regions. The most common method of encouraging development is to offer grants, loans, and loan guarantees to companies relocating or expanding in the region (Bennett, Graham and Banton, 1999). Recently, the idea among regional planners is to set in motion the interplay between companies within a common strategic area of knowledge (Lundequist and Power, 2002). This idea, labelled 'clusters' by regional economists (Hallencreutz and Lundequist, 2003), suggests that regions should identify and develop the existing regional competitive advantage (Porter, 2000). While the extant literature on the topic doesn't demonstrate, from a functionalist viewpoint, the value of clusters, the literature does recognise that the concept helps one think about longterm regional development strategies (Roberts and Enright, 2004).

The importance of industry clusters to economic development initiatives has resulted in a number of researchers attempting to identify clusters within a geographical area (see, for example, Bergmen and Feser, 1999). These researchers 
view clusters as an object that is "out there" awaiting impartial exploration and discovery (the positivist paradigm), but fail to provide relevant theories and variables to guide the empirical analysis. For instance, industry sectors for cluster development purposes are often chosen based on input-output analysis (Walzer et al, 2005). This technique identifies pairs of industry that are tied to one another through trade. The focus is on past and/or existing "trade-linkages" among industries, not on all plausible commonalities such as marketing communications and advertising intensity. This paper attempts to identify clusters using concepts borrowed from economic geography, industrial-organization theory, strategic-groups theory, cognitive psychology, and regional economics.

\section{THE ONTOLOGY OF CLUSTERS}

\section{Views from Economic Geography}

The field of economic geography explains interplay between companies using the principle of 'minimum differentiation' (Hotelling, 1929). According to this principle, product attributes of competing firms tend to be similar and consequently, firms tend to follow the same business strategy and thus form clusters. Three assumptions underlie this explanation: (i) linear product space with a uniform customer density in the space; (ii) relocation cost for firms is zero, and (iii) price elasticity of demand is zero. In this scenario, if one firm locates in the linear product space other than the centre of the space, the market is immediately divided into a long and a short segment. A new firm can enter the market and can gain more market share by locating close to the first firm but facing the longer segment of the market. Then the first firm can imitate the second firm's strategy, locating as close as possible to the second firm but facing the longer segment. This "leapfrogging" process can continue until both firms are located in the centre of the linear market. Note that in this scenario, shoppers will be indifferent to the firms and thus will choose a firm by a random process such as:

$$
\mathrm{f}(\mathrm{x}=\text { choice of store } \theta)=1 / \theta \quad \text { for } 0<\mathrm{x}<\theta ; 0 \text { elsewhere. }
$$

Several product attributes ranging from product quality to price can be used to partition the market. However, competitive advantage will result only if the product attribute is "valued" by the market.

This kind of reasoning implies that cluster analysis in a product-market region should be based on product attributes such as reliability, availability, etc. The objective of the cluster analysis is to identify or uncover clusters of firms that earn 
higher than normal economic profits. Once identified, such clusters should be supported by relevant networks of firms, and public policies, to sustain the region's competitive advantage.

\section{Views from Industrial Organization Economics and the Strategy Area}

Strategic groups theory, a modified industrial organization (IO) theory, offers another explanation for the existence of business clusters (Barney and Hoskisson, 1990). Briefly, IO economics, developed at the industry level, assume that firms in an industry are homogenous (Bain, 1968). This assumption was empirically tested and rejected by Hunt (1972); Porter (1979), and Newman (1978) - to mention a few. For instance, Hunt (1972) and Newman (1978) observed that the firms studied differed in terms of vertical integration, product differentiation and product diversification. Specifically, a finding of these studies is the presence of groups of firms pursuing similar strategies. The groups differed not only in strategies, but also in profits and sales levels. Hunt (1972) labelled these intra-industry groups, "strategic groups" (Barney, 1986).

Tang and Thomas (1992) observe that the concept of strategic groups advances IO economics by highlighting that firm strategy directly determines group structure and the performance of the industry. At a practical level, the concept of strategic groups suggests to managers that (i) a firm must overcome mobility barriers in order to move to a better performing group, and (ii) if the firm is already in a highperformance group, it should attempt to build mobility barriers: for instance, product quality, to protect the competitive advantage of the group.

Theoretical explanations of strategic groups focus on "differences in skills" among firms in an industry. For instance, Caves and Porter (1977) suggest that due to differences in skills, firms tend to invest in different mobility barriers and thus from different strategic groups. The choices that firms make on investments can be investments in advertising and/or investments in technology that they employ to conduct business. On the latter issue, Tang (1984) observes that firms that made historical investment in obsolete technology may not wish to move to an advanced high technology group because of cost considerations. Thus, the previous investments in technology create strategic groups with varying performance levels. Nath and Gruca (1997) add to this discussion by highlighting that causal ambiguity is a necessary condition for a mobility barrier to create strategic groups. For instance, mobility barrier due to investments in research and development cannot be easily overcome due to causal ambiguity. 
The "strategic groups" concept implies that regional economic development efforts should focus on high performance groups within an industry. Statistical cluster analysis is often employed to locate strategic groups (Barney and Hoskins, 1990).

\section{Views from Cognitive Psychology}

Cognitive research explains clusters using mental models of managers in an industry. The explanation starts with the recognition that simplification is a cognitive necessity in case of information overload. For instance, KOMPASS classifies hotels and motels in Sydney, Australia under the four-digit industrial or product classification code '69-10' (see KOMPASS AUSTRALIA, 29 ${ }^{\text {th }}$ ed., 2001, pp. 12661270). The list includes 32 hotels and motels within the Sydney region. If one attempts to analyse interconnectedness between these firms, then it requires:

$\{\mathrm{n}=32, \mathrm{r}=2, \mathrm{nCr}=496\}$ pair-wise analyses to model interconnectedness for each firm in SIC 69-10.

Research on mental models of managers suggests that managers simplify the task of independently analysing a large number of firms by grouping them (Miller, 1956; Schwenk ,1984; Reger and Huff, 1993). How is this grouping achieved? Porac, Thomas and Baden-Fuller (1989) posit that managers who work in the same industry environment develop shared perceptions or beliefs about industry groupings. These shared beliefs stem from the fact that managers interact with each other in industry meetings; share similar sources of information such as trade publications, business consultants, etc. Reger and Huff (1993) provide empirical support for this "cognitive" approach to grouping of firms.

The cognitive approach to cluster analysis is based on the interpretive paradigm (Berger and Luckmann, 1966). The interpretive paradigm requires the researcher to "uncover" clusters in a region based on qualitative procedures such as repertory grid technique (Kelly, 1955). Specifically, managers' beliefs about similarities and differences among firms in the industry are employed to identify high performance firms and thus clusters.

\section{Views from Regional Economics: The Porterian Model}

Porter $(1990,1998,2000)$ argues that a geographic region gains competitive advantage by developing clusters of "local" industries which are linked together through a range of supporting conditions. These supporting conditions include: factor conditions, demand conditions, related and supporting industries, and firm strategy, structure and rivalry. 
The salient implication of the Porterian model is that the supporting conditions should work as a system with each condition interacting with all the other supporting conditions. For instance, the performance of the wine industry in California depends on the interdependent networks of grape producers (factor conditions), large retail chains that demand value for money (demand conditions), testing and research firms (supporting industries), and competition from other alcoholic and non-alcoholic beverages (rivalry). A case in point would be the grape producers' fight against Pierce's disesase in Sonoma and Napa counties (Oritz, 2005). Pierce's disease devastated Southern California vineyards in 1999. To keep the disease from spreading, the wine grape industry implemented a self- imposed fee three years ago to fund disease research. The money, about $\$ 14$ million since 2002, has kept the disease at bay.

The Porterian model applies to most successful industries in most countries (see for example, Clancy, O'Malley, O'Connell and van Egeratt (2001); Porter (1990) for evidence in this direction). It is often employed to uncover clusters in a region based on the following procedures (Bradshaw, King \& Wahlstrom, 1999):

1. Identify dominant industries in the region based on statistical analysis of secondary data pertaining to a geographical area, for example, analyse employment data for industries in the Western Illinois region to discover competitive industries, and

2. Have stakeholders such as economic planners in the region to refine the list of industries identified in Step 1 to the most relevant ones for cluster development purposes. The strategic vision for the region could be used as a guide to this "culling" exercise.

\section{CONNECTING THE DIFFERENT VIEWPOINTS: AN INTEGRATIVE THEORY OF BUSINESS CLUSTERS}

\section{Precursors}

In the following pages, we employ the 'objective' and the 'stable' approach to theory building to construct an integrated theory of business clusters. Philosophers call this approach the 'functionalist paradigm' to theory building (Dubin, 1978). The adoption of the functionalist focus is deliberate since a multi-paradigm perspective is unlikely to move the discussion from theory to theory testing and refinement within a reasonable period of time.

The literature review highlights that most theories assume that groups of firms exist and some of them are high performers because of product-market factors (for 
example, the principle of minimum differentiation) and / or differential skills (for instance, advertising generated equity suggested by the strategic groups theory).

The next section of the paper explores the concept of "business performance" with a view to applying the concept to uncover or discover plausible clusters in a region. This is followed by a discussion about "competitive positions of industries". This concept is then employed to finalise the list of clusters derived based on business performance indicators.

\section{Industry Performance}

As mentioned earlier, business clusters are perceived to enhance regional economic growth and income (Barkley and Henry, 1998). The explanatory mechanism behind this assertion is that a rise in productivity determines real income in the region and, as defined by the Engel curve (Leeflang, Wittink, Wedel \& Naert, 2000), a rise in real income increases the demand for goods and services in the region. These increases induce further rises in real income - through the accelerator and income multiplier effects. Therefore, high performance industries have to be identified and analysed for cluster development purposes.

What is high performance? To address this question, we explore the antecedents and consequences of the construct. Put another way, we deduce the meaning of business performance using its relationship with other constructs.

IO economics lists environmental variables such as number of buyers and sellers, the existence of substitutes, etc. as antecedent variables to business performance (Caves and Porter, 1977). To this list, organization theorists add "organizational structure" (Daft, 2005). Briefly, varying degrees of environmental uncertainty demand either an "organic" form of business structure for adapting to changing needs of the markets, or a "mechanistic" form of structure to take advantage of the stability in the environment. In addition, business policy researchers (for example, Mintzberg, 1989) posit that organizations pursue purposive, directive course so the concept of "strategy" should be included as an antecedent variable. Figure 1 lists the antecedents for business performance identified through a meta-analysis on the topic (Capon, Farley \& Hoening, 1990).

Research suggests that environmental factors explain approximately $20 \%$ of variability in business performance and strategy factors explain most of the remaining variability (Powell, 1996; Rumelt, 1991). An implication of this finding is that researchers should measure business performance using both strategy and environmental variables. This is especially critical for cluster analysis since the 
theories reviewed above highlight the importance of strategy or differential skills to group membership (cf. strategic groups theory).

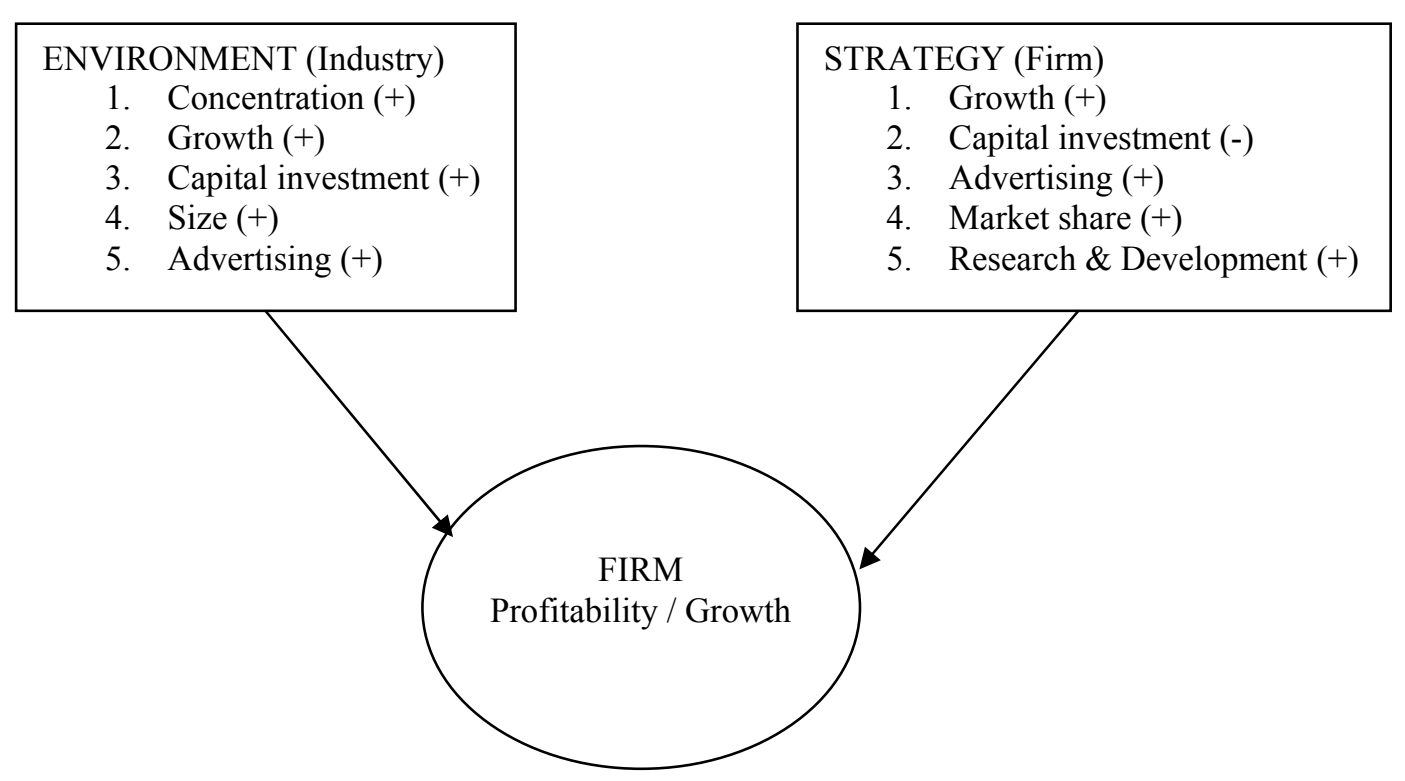

Figure 1 Determinants of Financial Performance: Adapted from Capon, Farley and Hoenig (1990)

Note: The "+" and "-“ signs denote the direction of the relationship with the criterion.

Once high performance groups have been identified, the next stage in cluster analysis is to "map" the competitive position of the chosen industry(s). We develop the conceptual scheme for such an analysis below.

\section{Analysing the Competitive Position of an Industry}

The Porterian model highlights that competitive advantage is a result of value creation in the marketplace. Conceptually, value could be defined as benefits less costs (Kotler, 2003). The study of strategy offers "value chain analysis" as a method to capture the value creation processes of firms (Davis and Devinney, 1997). Specifically, value-chain analysis examines processes within a firm to determine value-creating activities.

An approach similar to value-chain analysis that is applied at the industry-level is "value-system analysis" (Grundy, 1998). This technique enables one to examine how the various value chains in an industry are arranged vertically among companies in the industry. 
We theorise about the competitive position of an industry using a variation of the value-chain and the value-system approaches. The components of the conceptual framework include:

1. A business model: Value-added activities of firms in the industry. These would be a collection of activities that firms in the industry perform to be in business;

2. An assessment of "value adding" activities that are internal to industry in the study region (Indigenous value adding activities), and

3. An analysis of gaps between the business model and the indigenous value adding activities.

We begin with a discussion about business model for an industry. A business model describes the major activities that firms in an industry perform to be in business. We contend that a business model could be constructed by linking all the value adding activities of firms in the industry (value system analysis). These activities would be the industry's core value-adding activities. To this construction, we add the value adding activities of the domestic industry in the region (indigenous value adding activities). These are major activities that the domestic industry performs in the course of its business. Note that activities that are required but are not internal must be filled by network relationships.

Network relationships highlight both horizontal and vertical linkages of an industry. Specifically, it includes customers, suppliers, competitors, allies, regulatory agencies, etc. A simple flow-chart model such as the one shown in Figure 2 could help regional planners to look for gaps in performances in the domestic industry that are either being filled through network relationships or, are actual gaps in the value creating activities of the industry. Recruiting firms to the region would be one strategy to fill these gaps. Which firms would be good targets? This topic is explored in the next section.

\section{UNDERSTANDING POTENTIAL CLUSTER MEMBERS}

Earlier, we considered the "core" activities necessary to deliver a product to the market. In this section, the focus is on understanding potential network partners for cluster development purposes. Using market entry timing as the criterion concept, plausible "linkage" opportunities for the focal firm from similar upstream or downstream firms are assessed.

We start by defining the criterion concept: market entry timing. Market entry timing is the order of entry of firms into a product market. In measurement terminology, the natural variable is presumed to have properties that can be ordered 
sequentially, as the first entrant or the pioneer, second entrant, third entrant, and so on. In the following pages, we employ market entry timing to explain and predict cluster memberships.

We posit that three factors underlie order-of-entry into a cluster: firm, consumer, and status of the industry - a product life cycle indicator. Note that the three factors are interrelated. It is only for purposes of conceptual clarity that we categorize them and discuss them separately. We start by discussing firm factors.

Business Model for Medical Services: An Illustration
Online
Marketing
Community
Customer Support
Operations and IT
Shipping and
delivery
Billings and collections
Hardware and
Credit card
support services
services
Note: Internal capabilities (Indigenous value adding activities)

Overall Analysis for Cluster Development Purposes

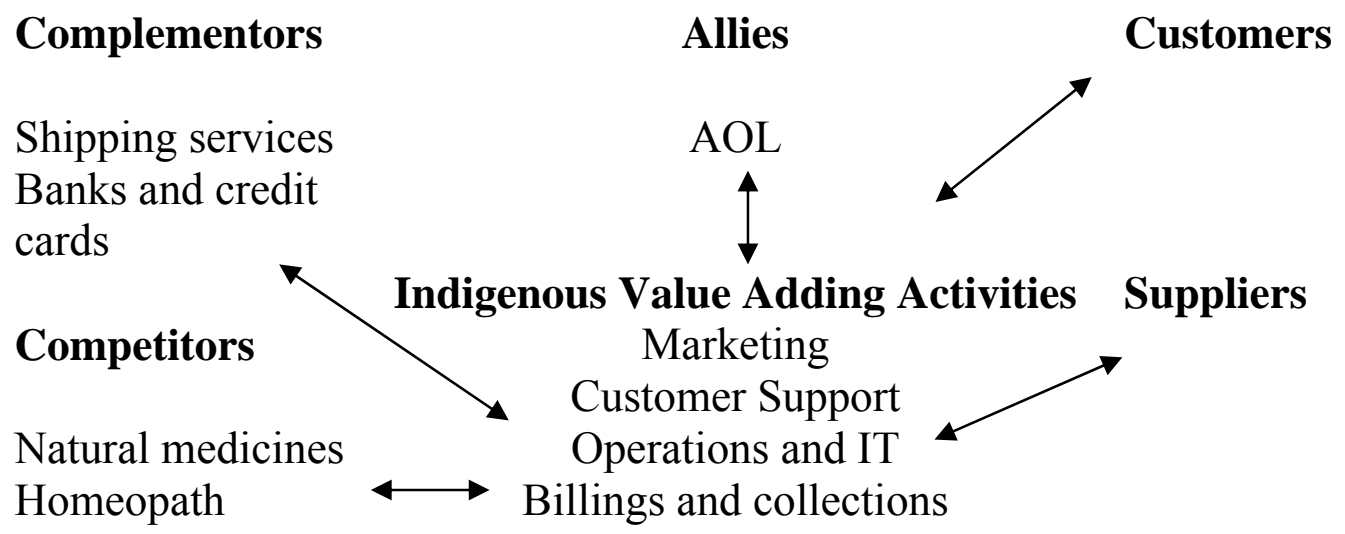

Figure 2 A Pictorial Representation of the Conceptual Model

\section{Firm Factors that Influence Cluster Membership}

Value chain analysis conceptualises firm's activities in a linear manner: for example, research and development, manufacturing, marketing, etc. Following that logic, we contend that a firm with production or manufacturing skills would be an early entrant into a new cluster initiative functioning in an industry that is in the introductory or initial phase of development. This is because the product is relatively easy to improve. On the other hand, a firm with marketing skills will be a late entrant 
into a cluster program functioning in a mature industry since cluster development at a more mature stage of the industry requires focusing on niche segments (Robinson, Fornell \& Sullivan, 1992). Hence the proposition:

P1: Possession of manufacturing skills is negatively related to order of entry into a cluster program, and possession of marketing skills is positively related to order of entry.

\section{Consumer Factors that Influence Cluster Membership}

While firm-specific factors "push" firms into cluster membership, consumer factors "pull" firms into membership. One such pull factor is, "consumer learning". Specifically, if product attributes are objective, that is, easy to evaluate, then success in the market will depend on educating customers about the product. In this case, firms with marketing skills will enter the cluster. However, research shows that consumer learning decreases with the number of firms with similar offerings functioning in the industry (Bowman and Gatignon, 1996). Indeed, Bowman and Gatignon's research shows that presence of multiple brands in an industry tends to decrease the market response to quality and promotion (see their Table 3, p.238).

On the other hand, if product attributes are difficult to evaluate, then the pioneer or the first entrants into the cluster have competitive advantage for at least two reasons. The first explanation is that when consumers successfully use the pioneer's brand, they will know with certainty that it works and thus will prefer it over the follower brands (Schmalensee, 1985; Robinson and Fornell, 1985; Golder and Tellis, 1993). Another explanation highlights that consumers may learn to equate the pioneer's product with the ideal product (Carpenter and Nakamoto, 1989). In either situation, firms with manufacturing skills will be the primary members. In summary, the discussion on consumer factors suggest the proposition that:

P2: If product attributes are objective, then firms with marketing skills will enter the cluster. If product attributes are difficult to evaluate, then, firms with manufacturing skills will form the cluster.

\section{Industry Factors that Influence Cluster Membership}

Yet another consumer factor that favours early entry over later entry into cluster is the 'network effects', i.e. the influence of triers or adopters of the product on nonusers or potential purchasers of the product (Eliashberg and Robertson, 1988). The impact of these effects is more pronounced on socially conspicuous consumption 
(Kotler, 2003). For instance, products such as cellular phones and automobiles rely on network effects to succeed at the marketplace. Thus, it is likely that manufacturers of social products benefit more from these network effects. Thus:

P3: For social products, cluster formation will be driven by manufacturing firms.

For privately consumed products, cluster formation will be driven by marketing firms.

Switching costs is another industry-specific concept that can be associated with cluster membership. Switching costs are one-time costs incurred by the consumer for adopting a new product or converting to the new product (Eliashberg and Robertson, 1988). Note that switching costs would include the purchase price of the product and the related costs of changing the consumption system. Logically, if the switching costs are high, then one would expect the early entrants to the cluster program to gain the most. Thus:

P4: In product-markets with high switching costs, manufacturing firms would drive cluster formation.

In summary, we posit that firms with manufacturing and research and development skill would be the first entrants to a cluster program. Possession of marketing skills is related to late entry into the cluster. Also, the attraction to a cluster will differ from one consumer-learning situation to another. For example, if the product is easy to evaluate, then success in the product-market will depend on educating the customers about the brand. In this scenario, firms with marketing skills will find clustering attractive.

\section{Dynamics of Clusters}

Earlier, it was shown that the likelihood of cluster formation is influenced by firm-specific characteristics such as manufacturing skills and industry features such as consumer learning within the product category. Based on the above, it is possible to infer the likely cluster characteristics over time.

\section{CLUSTER STRUCTURE}

The classical product life cycle suggests that products move from the introductory phase, through to growth, maturity, and decline stage (Kotler, 2003; Levitt, 1965). Applying this concept to cluster formation and development suggests the following generalizations. 
During the introductory phase of the industry, it is highly likely that the production technology is still evolving. In this scenario, the cooperation will be confined mostly to product innovation and development. In line with Robinson, Fornell and Sullivan (1992), only few firms with R\&D skills will exist in the industry. The firms' marketing activities will be directed at inducing both primary demand and primary sales (Hanssens, Parsons \& Schultz, 1990). During this phase, it is possible that consumers' preference becomes shaped by one of the first entrants (Carpenter and Nakamoto, 1989). In other words, since the attributes of the product may be difficult to evaluate by most, if not all consumers, the pioneer's product or one of the first entrants' product, will become the industry standard (see Figure 3).

The evolution of a brand as the industry standard will result in firms directing their attention to the production or manufacturing process. The emphasis will be on low delivered cost. Note that this argument is in line with Cooper and Nakanishi's (1989) observation that competition reduces competitive offerings to important attributes. Also, in this scenario, it is logical to expect firms with manufacturing skills to enter the industry (Robinson, Fornell \& Sullivan, 1992). In general, the strategic focus will shift towards upstream activities. Downstream activities will be directed primarily at inducing primary sales and advertising elasticity will be the highest (Hanssens, Parsons \& Schultz, 1990). The distribution of the product will be intensive.

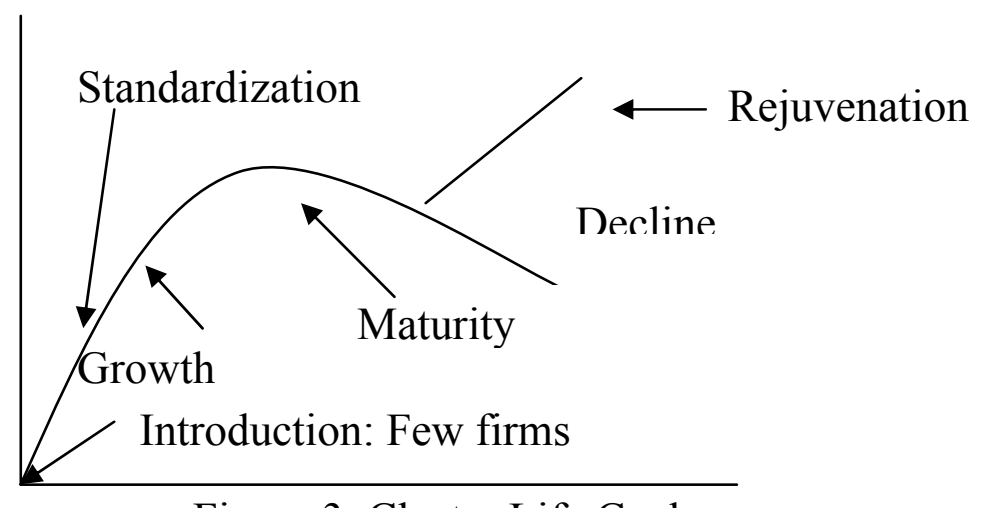

Figure 3 Cluster Life Cycle

During the maturity stage of the life cycle, it is highly likely that firms with marketing skills will enter the cluster. This is the stage when downstream activities, will be at their peak. Figure 4 is a pictorial summary of the discussion. 


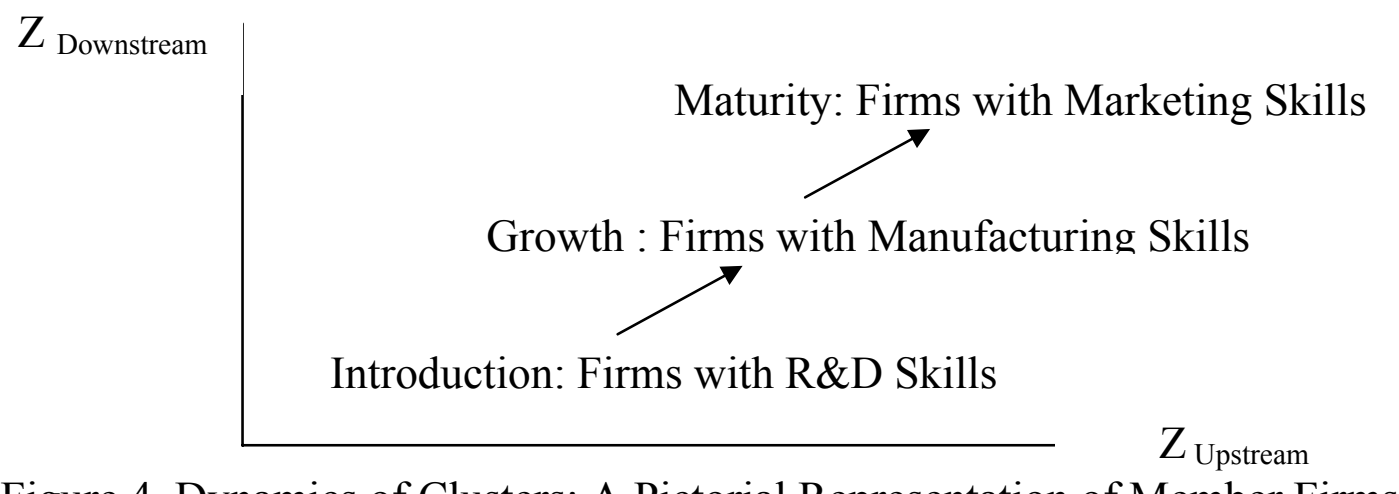

Figure 4 Dynamics of Clusters: A Pictorial Representation of Member Firms

\section{SUMMARY AND CONCLUSION}

This paper reviews the meaning of business clusters that can be found in the extant literature and observes that the existing definitions of clusters can be grouped under two categories: intra-industry clusters, and inter industry clusters. Economic geographers, and strategy researchers suggest "intra industry" conceptualisations of clusters. Regional economists subscribe to the Porterian model of clusters that focuses on inter-industry linkages. While we agree that clusters should assess interindustry linkages, we argue that the process of identifying clusters should begin at the intra-industry level.

Four decades of research in IO economics and strategy area reveals the existence of intra-industry groups of firms with group-specific differences in performance levels. Hence, we argue that the first step in cluster analysis is to locate such high performing "strategic groups" in different industries. The next step in the analysis is to explore the competitive capability of the strategic groups. A modified version of value chain analysis could be employed to gain insights into the competitive capabilities of strategic groups. This analysis would help regional planners to identify gaps in capabilities of domestic industries, and to choose one or more strategic groups for cluster development purposes. Finally, we theorise about the dynamics of clusters. Specifically, we highlight the type of firms that would be receptive to the idea of cluster membership. Future research should test the applicability of the model for uncovering and developing clusters. 


\section{REFERENCES}

Bain, J. S. (1968). Industrial Organization. New York: John Wiley.

Barkley, D. L., \& Henry, M. S. (1998). Rural industrial development: to cluster or not to cluster?" Review of Agricultural Economics, 19, 308-325.

Barney, J. (1986). Organizational culture: Can it be a source of sustained competitive advantage? Academy of Management Review, 11(3), 656-665.

Barney, J., \& Hoskisson, R. E. (1990). Strategic Groups: Untested Assertions and Research Proposals. Managerial and Decision Economics, 11, 187-198.

Bennett, R., Graham D. J., \& Bratton, W. (1999). The Location and Concentration of Businesses in Britain: Business Clusters, Business Services, Market Coverage and Local Economic Development. Transaction of the Institute of British Geographers, 24(4), 393-420.

Berger, P. L., \& Luckmaan, T. (1966). The social construction of reality. In P. L. Berger., \& T. Luckmaan (Eds.). The social construction of reality: A treatise in the sociology of knowledge. New York: Random House, Doubleday.

Bergmen, E. M., \& Feser, E. (1999). Rural Industrial Cluster: to Cluster or Not to Cluster. Review of Agricultural Economics, 19(2), 308-325.

Bowman, D., \& Gatigon, J. (1996). Order of Entry as a Moderator of the Effect of the Marketing Mix on a Market Share. Marketing Science, 15(3), 222-242.

Bradshaw, T. K., King, J. R., \& Wahlstrom, S. (1999, June). Catching on to Clusters. Planning, 18-21.

Caves, R., \& Porter, M. E. (1977). From Entry Barriers to Mobility Barriers: Conjectured Decisions and Contrived Deterrence to New Competition. Quarterly Journal of Economics, 91, 241-267.

Capon, N., Farley, J., \& Hoening, S. (1990). Determinants of Financial Performance: a Meta Analysis. Management Science, 36(10), 1143-1159.

Carpenter, G. S., \& Nakamoto, K. (1989). Consumer Preference Formation and Pioneering Advantage. Journal of Marketing Research, 26(3), 285-298.

Clancy, P., O’Malley, E., O’Connell, L., \& van Egeraat, C. (2001). Industry Clusters in Ireland: An Application of Porter's Model of National Competitive Advantage to Three Sectors. European Planning Studies, 9(1), 7-28.

Cooper, L. G., \& Nakanishi, M. (1989). Market-Share Analysis. Boston: Kluwer Academic Publishers.

Daft, R. T. (2005). Organization Theory and Decision. New York: West Publishing.

Davis, J., \& Devinney, T. (1997). The Essence of Corporate Strategy: Theory for Modern Decision Making. Sydney: Allen \& Unwin. 
Dubin, R. (1978). Theory Building. New York: Free Press.

Eliashberg, J., \& Robertson, T. (1988). New Product Preannouncing Behavior: A Market Signaling Study. Journal of Marketing Research, 25(3), 282-292.

Golder, P. N., \& Tellis, G. (1993). Pioneer Advantage: Marketing Logic Or Legend? Journal of Marketing Research, 30(2), 158-170.

Grundy, T. (1998, December). Managing the Business Value System. Management Accounting, 30-32.

Hallencreutz, D., \& Lundequist, P. (2003). Spatial Clustering and the Potential for Policy Practice: Experiences from Cluster-building Processes in Sweden. European Planning Studies, 11(5), 533-547.

Hanssens, D. M., Parsons, L. J., \& Schultz, R. L. (1990). Market Response Models: Econometric and Time Series Analysis. Boston: Kluwer Academic Publishers.

Hotelling, H. (1929). Stability in Competition. Economic Journal, 39, 41-57.

Hunt, M. (1972). Competition in the Major Home Appliance Industry, 1960-1970 (Doctoral dissertation, Harvard University,1972).

Kelly, G.A. (1955). The Psychology of Personal Constructs. New York: W.W. Norton \& Company Inc.

Kotler, P. (2003). A Framework for Marketing Management. Upper Saddle River, NJ Prentice Hall.

Leeflang, P., Wittink, D. R., Wedel, M., \& Naert, P. A. (2000). Building Models For Marketing Decisions. Boston : Kluwer Academic Publishers.

Levitt, T. (1965). Exploit the product life cycle. Harvard Business Review, 43, 8194.

Lundequist, P., \& Power, D. (2002). Putting Porter into Practice? Practices of Regional Cluster Building: Evidence from Sweden. European Planning Studies, 10(6), 685-704.

Miller, G. A. (1956). The magical number seven plus or minus two: Some limits on our capacity for processing information. Psychological Review, 63, 81-97.

Mintzberg, H. (1989). Mintzberg on Management, Inside Our Strange World of Organizations. London : Free Press.

M. Tang (1984). Generic strategy and the product life cycle. Sloan School of Management Working Paper, 1601-1684.

Nath, D., \& Gruca, T. S. (1997). Convergence across alternative methods for forming strategic groups. Managerial and Decision Economics, 18(9), 745-760.

Newman, H. H. (1978, August). Strategic Groups and the Structure-performance Relationship. Review of Economics and Statistics, 60, 417-427. 
Oritz, J. (2005, March 21). Pinot Pest, Knight Ridder/Tribune Business News, 1-2.

Porac, J. F., Thomas, H., \& Baden-Fuller, C. (1989). Competitive groups as communities: The case of Scottish knitwear manufacturers. Journal of Management Studies, 26, 397-416.

Porter, M. (1979). How competitive forces shape strategy. Harvard Business Review, March-April, 93-101.

Porter, M. E. (1990). The Competitive Advantage of Nations. New York: Free Press.

Porter, M. E. (1998). Clusters and the New Economics of Competition. Harvard Business Review, November, 77-90.

Porter, M. E. (2000). Location, Competition, and Economic Development: Local Clusters in a Global Economy. Economic Development Quarterly, 14(1), 15-34.

Powell, T. C. (1996). How Much Does Industry Matter? An Alternative Empirical Test. Strategic Management Journal, 17(4), 323-334.

Reger, R., \& Huff, A. (1993). Strategic Groups: A Cognitive Perspective. Strategic Management Journal, 14(2), 103-124.

Roberts, B. H., \& Enright, M. (2004). Industry Clusters in Australia: Recent Trends and Prospects. European Planning Studies, 12(1), 99-121.

Robinson, W., \& Fornell, C. (1985). Sources of Market Pioneer Advantages in Consumer Goods Industries. Journal of Marketing Research, 22(3), 305-317.

Robinson, W., Fornell, C., \& Sullivan, M. (1992). Are Market Pioneers Intrinsically Stronger Than Later Entrants? Strategic Management Journal, 13, 609-624.

Rumelt, R. (1991). How Much Does Industry Matter? Strategic Management Journal, 12(3), 167-185.

Schwenk, C.R. 1984. Cognitive simplification processes in strategic decision-making. Strategic Management Journal 5(2), 111-128.

Schmalensee, R. (1985). Do Markets Differ Much? American Economic Review, 75(3), 341-351.

Tang, M., \& Thomas, H. (1992). The concept of strategic groups: Theoretical construct or analytical convenience? Managerial and Decision Economics, 13(4), 323-329.

Walzer, N., Shumway, L., \& Gruidl, J. (2005). Potential Clusters and Related Industries in LWIA-14 Region. IL: Illinois Institute for Rural Affairs. 